\title{
Critical thinking in the context of clinical practice: The need to reinvent pharmacy education
}

\author{
Erika Lourenço de Freitas ${ }^{i}$ \\ Regis University, EUA \\ Djenane Ramalho-de-Oliveiraii \\ Universidade Federal de Minas Gerais, Brasil
}

\begin{abstract}
In order to understand how pedagogical practices influence pharmacy students' development of critical thinking skills, we used critical ethnography and the methods of participant observation, focus groups and in-depth interviews with students and faculty from one of the top ten Colleges of Pharmacy in the United States. The results that emerged from two semesters of fieldwork engagement suggested that the traditionally taught pharmaceutical knowledge isn't enough to prepare pharmacy students for clinical practice. Besides the ability to retrieve information, pharmacy education can benefit from the incorporation of experiential learning and the pharmaceutical care philosophy and theoretical framework into the curriculum to prepare pharmacists to provide direct patient care. The knowledge that emerged from this study will allow educators to design learning activities to more effectively develop these essential skills in our future caregivers.
\end{abstract}

Keywords

Pharmacy education; Clinical practice; Pharmaceutical care; Qualitative research

\section{Critical thinking and pharmacy education: Why should we} care?

The pedagogical processes through which students are supposed to become more reflective are an important issue in preparing healthcare 
professionals who are also critical thinkers. The critical thinking tradition relies on the belief that the ability of humans for 'good reasoning' can be nurtured and further developed by an educational process aimed directly to that end, as well as by the maturity brought by practice experience (Paul, Elder, \& Bartell, 1997; Seldomridge \& Walsh, 2006).

'Good reasoning' is certainly in consonance with what bell hooks (2010) calls "good education": not just one that gives students knowledge and prepares them for a vocation, but also a process that encourages an ongoing commitment to social justice. Education is, in a large part, a socialization process and, as such, it is not an end in itself. On one hand, it serves to socialize individuals into a professional role and provides them with a social identity, shaping values, attitudes, and the broader dimensions of behavior that are appropriate to the group (Strand \& Morley, 1987). On the other hand, it can contribute to social transformation, playing a fundamental role as one more key feature in the society's rebuilding and constant reinvention.

According to Shor and Freire's perspective (1987), it seems fundamental that teachers and students understand that the educational process should not be an act of simply mastering "a manual of clever techniques". Rather, education should be taken as an opportunity to "critically reorient students [and teachers] to society", understanding that the social context of teaching and learning makes it a great opportunity for crafting social transformation. Critical thinking seems to be a fundamental skill embedded in this process. However, the literature in the pharmacy field fails to identify or provide a version of critical thinking definition that would be suitable for the clinical practice adopted by the pharmacy profession. The philosophy of pharmaceutical care practice proposes a patient-centered approach and a caring paradigm that demand pharmacists to use different types of knowledge and skills as they work directly and take co-responsibility for the health of their patients.

In this new professional paradigm, pharmacists certainly face difficult choices concerning what is best for their patients, especially in this rapidly changing healthcare environment. It is no longer good enough to master pharmacological knowledge or to merely identify needs and demands of patients and healthcare organizations. Pharmacists are now expected to be able to analyze complex and singular situations and to make clinical decisions 
based on a wide range of knowledge - social, clinical, philosophical - and experiences. The ability to think critically, therefore, becomes paramount in this process of embracing the practice of direct patient care.

Perhaps this realization forms part of the basis for why society is currently demanding a broader range of learning outcomes from the educational system in general. Knowledge and skills cannot be the only staples of the educational philosophy that prepares healthcare professionals for the workforce anymore. There is a clear urge for a broader set of outcomes including habits of mind and dispositions, such as civic engagement, social responsibility and commitment to the common good that must be taken in consideration as we work to equip people to improve their own futures and become active members of society, as citizens and as healthcare professionals.

Critical thinking is about how one approaches problems, questions, issues. Becoming educated and sharpening the ability to make fair judgments does not absolutely guarantee a life of happiness, professional and financial success or virtue, but it might offer a better chance at those things. Experts affirm that "critical thinking is a pervasive and purposeful human phenomenon" (Facione, 2013) and that it is characterized not only by her or his cognitive skills, but also by how she or he approaches life and living in general.

\section{A. Critical thinking, clinical practice, and pharmacy education}

The healthcare field is not immune to the process of incorporating critical thinking expertise into the desired outcomes of its educational process. The dynamics of knowledge production and acquisition is placing increasing demand on flexible intellectual skills, and on the ability to analyze information and integrate diverse sources of knowledge in solving complex problems (Bartlett \& Cox, 2002).

Back in 1987, Strand and Morley stated that pharmacy education, at that time, was committed to a conservative goal to educate/ train individuals not so much to become agents of change, but rather to fit into the prevailing status quo. But time has changed - and so have the stakes. The discourse in pharmacy education has evolved. In July 1989, the American Association of Colleges of Pharmacy formed the Commission to Implement Change in 
Pharmacy Education, whose task was to evaluate the role of Pharmacy in the future and to make recommendations to guide pharmacy education as it evolves to meet the changing demands of the profession, the healthcare system and society. At that time, the Commission declared a radical change in pharmacy practice, stating that "the mission of pharmacy practice is to render pharmaceutical care" (American Association of Colleges of Pharmacy [AACP], 1989).

Pharmaceutical care is a professional health care practice in which a practitioner takes responsibility for meeting a patient's drug related needs by preventing, identifying, and resolving drug therapy problems (Cipolle, Strand, \& Morley, 2012). Two fundamental assumptions of pharmaceutical care - the clinical encounter between pharmacist and patient and the collaboration with different members of the health care team - introduced different requirements in terms of skills and abilities needed to accomplish this new professional role.

Acknowledging the urge for changes in pharmaceutical education, Droege (2003) wrote that

[i]f practicing pharmaceutical care requires a shift in focus from drug product to patient, so does teaching future practitioners. The curriculum would have to address issues that go beyond didactic and experiential courses; it would also have to include environmental, cultural, and social components that can help to build a new conceptual framework of a professional practice. (p. 72)

Colleges and schools of pharmacy have responded to the call for the pharmaceutical education reform by implementing changes to promote the desired outcomes. Several accreditation standards have been created in order to better prepare pharmacists for teamwork practice in direct patient care scenarios. In 1991, the Commission to Implement Change in Pharmaceutical Education published a background paper (AACP, 1991) that spoke directly to critical thinking in pharmacy education:

Although critical thinking is a universally desired educational outcome, professionals particularly need a repertoire of thinking strategies that will enable them to acquire, evaluate, and synthesize information and knowledge. Since much of professional practice is problem-solving, students need to develop analytical skills to make decisions in both familiar and unfamiliar circumstances. Critical thinking fosters a questioning attitude among professionals, and it is a prerequisite skill in making judgments. 
Similarly, the Accreditation Council for Pharmacy Education (Accreditation Council for Pharmacy Education [ACPE], 2006) endorsed critical thinking in pharmacy curricula through several accreditation standards and guidelines, in the "Accreditation Standards and Guidelines for the Professional Program in Pharmacy Leading to the Doctor of Pharmacy Degree", adopted in 2006. Without defining what is meant by critical thinking, this document directs colleges and schools of pharmacy to use teaching, learning, and assessment methods to foster the "development and maturation of critical thinking skills".

It is evident that pharmacy education has been placing an increasing emphasis on critical thinking as the profession transitions to a patient care role, but the question of what critical thinking means in this context remains unanswered (Phillips, Chesnut, \& Rospond, 2004). The challenge to teach and assess critical thinking as an educational outcome remains because standards of practice do not guarantee a well-prepared pharmacist, since the accreditation standards do not address how practice skills and knowledge must be integrated and applied in order to be effective.

Strand and Morley (1987) stated that in order to train strong critical thinkers and proficient problem solvers it is absolutely essential to begin with a critical examination of the educational process itself. Also, experts fear that some of the things people experience in school might be actually harmful to the full development and cultivation of strong critical thinking skills (Facione, 2013). This research was an attempt to unveil the potential of the classroom as one more space likely to influence the development of those skills and dispositions.

What should be taught and learned in pharmacy's classrooms seems to be clear from all the guidelines that are driving the PharmD curriculum in the United States. However, several important questions related to critical thinking in the pharmacy profession were still unattended when we decided to conduct this research, including: what does critical thinking mean to students and faculty in the context of preparing pharmacy students to clinical practice in the healthcare scenario?

With this question in mind, we grounded the research process on an ethnographic methodology informed by critical theory. Our major goal with this research was to contribute to a body of knowledge that can transform the 
educational process to prepare healthcare students. If closely observed, the results of this study might help faculty and curriculum stakeholders to better prepare pharmacy students to use their skills to make meaningful contributions to patients' lives.

\section{Methodology and methods}

This study was designed to describe and analyze pedagogical practices in pharmacy classrooms through the process of in-depth engagement in classroom activities that took place in several courses at one of the top ten Colleges of Pharmacy in the United States. The fieldwork engagement through participant observation lasted the entire Spring semester of 2012.

Ethnography is notoriously eclectic in its employment of multiple methods of data collection (Wolcott, 2005). Since the main interest embedded in this study was to unfold the layers involved in teaching and learning critical thinking skills in classrooms focused on patient care, we conducted participant observations in three courses focusing either on pharmaceutical care or in applied pharmacotherapy in the first, second, and third professional year of pharmacy school. The course directors of the three aforementioned classes agreed with our presence in their classrooms. The 4th professional year (PD4) was not included in this study because the last year of the Pharmacy course is dedicated to Advanced Pharmacy Practice Experience, which occurs in diverse pharmacy practice scenarios, outside the classroom. The courses were selected based on their clear statement of focus on patient care and also based on the intention of observing a variety of teaching and learning environments and practices at the university (classrooms and laboratories, lectures and practical activities).

Fieldnotes were an important part of the process of data collection. During the observation time, the researchers would jot down keywords of phrases and, immediately after class, we used them to construct evocative descriptions of the scenes observed. Also, as part of the participant observation process and whenever possible, we frequently engaged in informal conversations with students during the class breaks. In-depthinterviews (Rubin \& Rubin, 2005) were conducted with 10 key-informant students and 23 professors and course directors at the College of Pharmacy. 
We also conducted three focus groups with a total of 24 students from the first, second, and third year of pharmacy school. The purpose of the focus groups was to develop a broad understanding of issues related to developing critical thinking abilities, as they are taught/required in the classroom. The three focus groups were announced in each class being observed. We worked closely with the class representatives to identify the best dates and times when students would likely be less busy with classes and exams and we set three dates to conduct the focus groups. Each focus group lasted one hour and the students who volunteered did not receive any financial compensation for participating, but they were offered lunch boxes.

\section{A. Data analysis}

The transcripts from the interviews, focus groups, and fieldnotes were analyzed in an ongoing process throughout the research period. The qualitative data analysis software NVIVO 10 was used, which allowed us to collect, organize, analyze the content from all interviews, focus groups, and fieldnotes. It provided us with search, query, and visualization tools that facilitated the process of data analysis. The analysis followed that one described by Emerson, Fretz, and Shaw (1995).

The next step was to combine the close data reading with procedures of analytically coding fieldnotes on an ongoing basis. This process proceeded in two different phases: 1) the open coding, when the fieldnotes were read line-byline, and we used the software feature "Nodes" to mark the main ideas or topics that emerged, no matter how varied and disparate they were. This work was subsequently revised, with the objective to identify "key", "rich" or "revealing" incidents that were especially informative to the research question. We also kept writing reflective entries using the "Memos" feature to help us achieve a better grasp of the data. Then, all the codes and the respective statements were reviewed and combined if they would overlap or share meaning. We used then a smaller set of promising ideas and categories to construct the major topics and themes for the final ethnographic account here presented.

This study was approved by the Institutional Review Board (IRB) Committee of the University and all participants provided us with oral and written consent. 


\section{Results}

\section{A. The ability to retrieve information}

Both faculty and students were aware of the fact that it seems impossible to teach and learn everything at school, given the fast pace of changes we are facing nowadays in the healthcare field and the short time, during the professional education, to cover all the information. As highlighted by Lopes, Vieira, and Moreira (2014), technology is an essential component of the new contexts and challenges presented by our contemporary lifestyle. According to them, technology can be seen as both unlimited source of knowledge and opportunity, as well as a significant risk of exclusion for those ones who do not possess the appropriate competency in this field. Therefore, in the healthcare arena, critical thinking must include the ability to retrieve the needed information that would be necessary to provide optimum patient care.

And what we tell the students is we're not going to teach them everything. They're going to learn the skills that they need, they're going to be able to figure out on their own whether it's the drug information skills or whatever they need. I'm not going to teach them every drug in the book. That's not going to happen. Too short of a time in pharmacy school. - Faculty.

The generic calls found in the literature to teach students to make better judgments and reason more logically are deeply rooted in the fact that practitioners frequently must make complex decisions affecting patient care. Those decisions are inevitably influenced by the vast amount of information available in the healthcare field and it is frequently incomplete and imperfect (Austin, Gregory, \& Chiu, 2008). Therefore, practitioners must be able to connect and extrapolate pieces of information and make reasoned judgments based upon the best available evidence (Facione \& Facione, 2008). In clinical practice, it might go from good interviewing skills to learning how to analyze a paper and decide whether the gathered information is accurate/reliable or not.

Faculty and students emphasized that the access to information is not the limiting factor to a successful intervention in healthcare anymore. As long as the professional has access to technology, the information is at his/her fingertips. The key, according to the participants, is to know what questions to ask and where to look for the answers:

And in my opinion, that's what [critical thinking] essentially is - we live in an age, today, where you can look up any information. Resources are basically 
unlimited. You can find anything you need to know about a drug, about anything, if you just know where to look and have the skills to be able to access it and a framework to put it into. - Student, interview.

Curiosity was also mentioned as the engine that propels people to dig deeper, think harder. As put by a faculty member, in order to be a strong critical thinker "you have to think of yourself as sort of a detective. Like, you have to be curious, and you have to dig in to get at that and ask: 'What am I missing?"'. This dispositional component identified seems to be intimately related to the "inquisitiveness with regard to a wide range of issues" and the "concern to become and remain generally well-informed", which are two of the affective dispositions of critical thinking listed in the consensus expert published by the American Philosophical Association (Facione, 1990). Some faculty members went as far as affirming that it is not possible to be a strong critical thinker without having curiosity. Whether it is possible to teach it or not, they were not so sure. But there was a common belief, among those who mentioned curiosity as a dispositional component of critical thinking, that it is possible to create spaces in the classroom for students to be curious about.

For example, when we say: "This is the article and here are the questions that you have to answer", the students will go ahead and probably answer these questions. But how many other questions should they be asking themselves when they are reading the article? - Faculty.

While striving to place the various aspects of critical thinking concept used in pharmacy within the larger body of literature currently available on this subject, we identified two themes that were highly associated with critical thinking in pharmacy, even though not directly related to its core definition. The first one refers to the factors that might foster or deepen critical thinking abilities in the classroom and the second one is related to the particularities of thinking critically in pharmacy when students are learning to take care of patients. We named them "the catalytic factors" and "the algorithm of thinking", respectively, and we offer a more detailed description of these themes in the subsequent sections.

\section{B. Catalytic factors}

Faculty and students were in agreement that both background knowledge and hands-on experience would foster critical thinking abilities in 
the classroom. Previous knowledge provides the starting point, the "seed" that leads to further investigation. This previous knowledge seems to be what leads and directs one in his/her search for new information: where to dig? How far to go? Critical thinking is, by a certain extent, an expansion of those horizons of knowledge into a more suitable answer to the question being considered.

Similarly, experience was seen as one of the most effective ways to learn to think critically. In fact, some participants mentioned it as the only way to actually learn critical thinking skills. The general idea is that experience makes the learned information to "stick better", so one can build on that 'internalized concept' when facing a novel situation. This student summarized very well how those 'catalytic factors' work together, allowing one to apply critical thinking skills:

Well, you've got to know something in order to make decisions. You have to know drug classes, and indications, and contraindications. You have to know certain facts; a lot of facts. And then also you need to know, I guess, based on our education we hopefully are trained a little bit on how to look up information if we don't know it. But then, after we learn how to do those things and we have all these facts, then we can apply it to a real life situation. The more you apply that, the more experience you have and the easier it becomes and probably the better answers and solutions you're going to come up with, I would think. Student, focus group.

\section{B.1. Background knowledge}

Students and faculty were unisonous in claiming that one is not able to think critically regarding a certain subject matter without having the basis of the knowledge to do so. In this context, critical thinking was again highly associated with problem solving skills. Although critical thinking is regarded by experts as a set of skills that can be used at any time, in any context, they do recognize that thought processes are intertwined with what is being thought about (Facione, 1990; Willingham, 2007).

Regardless of the relative value of knowledge for the mastery of critical thinking skills, the questions of what should be called "knowledge" and by which means it should be taught and learned ought not to be left alone, as they are the core of any educational process. A participant made the clear connection between the knowledge basis allegedly needed to apply critical thinking and the justification of memorization as a required skill in the learning process: 


\begin{abstract}
You cannot apply critical thinking skills if you don't know anything. Sometimes I hear people making this statement that memorization is never important or that core content doesn't need to me memorized... And I strongly, strongly oppose that viewpoint because you have to know something to be able to apply it. Faculty.
\end{abstract}

Memorization was a common theme extensively discussed by students and faculty, some of them stressing its importance, and some of them pointing out its detrimental effects in the process of 'achieving knowledge'. Paul (1990) contributes to this discussion when he asserts that

Knowledge is not something that can be given by one person to another. It cannot simply be memorized out of a book or taken whole cloth from the mind of another. Knowledge, rightly understood, is a distinctive construction by the learner, something that issues out of a rational use of mental processes. (p. 523)

In this sense, the direct correlation between memorization and knowledge might be profoundly detrimental to the development of critical thinking skills. Caution is warranted when such conception is still part of the repertoire of teaching and learning strategies used by faculty, students and curriculum stakeholders, especially when they are invested in a curriculum that expects critical thinking to be one of its main educational outcomes.

\title{
B.2. Experience
}

The idea of applying a known method, principle, or theory to a novel situation connected to patient care supported the argument that experience furthers critical thinking. By 'applying' it, students not only put in practice an abstraction learned, but they also accumulate experience that will be a valuable tool to interpret and evaluate a future novel situation. Taking a critical thinking approach to clinical practice seems to entail two essential, linked goals: accurate problem identification and optimal problem resolution. Experts agree that experience may actually sharpen the ability to solve problems by assessing evidence using valid inferences, abstractions, and generalizations (Scott, Markert, \& Dunn, 1998).

Most of what we teach and learn is intended for application to solve complex problems in real life and it is a strong indicative of the importance of application objectives in the general curriculum. It would not be difficult to conclude, then, that the effectiveness of a large part of the educational effort 
is dependent upon how well the students retain and apply the learned concepts to situations or problems never faced in their learning process (Bloom, 1956). According to these findings, students learn from each patient simulated or real - and they are encouraged to incorporate those learned lessons into a new situation, with new patients.

(...) real patients, real scenarios. I mean, previously in class it was always like a grading rubric. I had to get the right answer based on what the grading rubric was. But in the real world there sometimes isn't a right answer. And so, having that really made me a critical thinker. - Student, face-to-face interview.

Students who had the chance to work with simulated patients in lab or that had contact with real patients during their Introductory Pharmacy Practice Experience (IPPE) - like the one quoted above - cherished the experience and highlighted its importance for the development of critical thinking skills. Participants of this study were in agreement that, when it comes to making clinical decisions from a critical thinking standpoint, "one size does not fit all". The same clinical situation might accommodate a multitude of suitable answers and the key factor in deciding what to do comes down to what would be the best fit for that specific patient. The experiential component of curriculum delivery, according to the participants of this study, was designed to build skills and strengthen what students have learned in the classroom.

Patient centeredness emerged in this study as an essential component of thinking critically in pharmacy, as suggested by these participants:

We are moving now to a much more patient focused approach. Drugs, chemicals tend to behave the same all the time. Patients are much more complex than that [laughter]! You know, you put them in the same situation and they may respond differently than they did the last time, because what they just did changed the way that they would think about responding to it. - Faculty.

In this sense, the most important contribution of the experiential component of education is its ability to expose the students to the "grayness and complexity of patient care". Participants emphasized that, in the real world, there are no straight answers. There is no straight right or wrong. There is the best for that specific patient, in a specific condition. The ability to incorporate the patient factor in all its grayness in the plan for action revealed to be an important trait of critical thinking in pharmacy education. Being 'patient-centered' represents a step towards better outcomes in this thinking process. 


\section{The algorithm of thinking}

'Algorithm' was one of the words frequently used by some participants to explain the thought processes that have been taught in pharmacy classrooms. Closely associated to the idea of algorithm was the term "thought process", meaning those same rational steps that a pharmacist should go through, when taking care of patients, to make clinical judgments without "missing something" that might be important to the quality of care provided. According to the participants, the mastery of this thought process equates to critical thinking in pharmacy when the focus is to take care of patients. When asked for a concrete example of the application of this "thought process", a student offered the following explanation:

So the patient has a problem or the patient has something that he is coming to you for, for a service or an outcome that they want. Critical thinking is taking all the information that they [patients] present - that you have been educated and know how to take - and piecing together a care plan based on their values, on their objectives, the whole subjective-objective information, all those things in a way that enables them [patients] to live to the best quality of life or length that they desire. Based on their own culture, based on their own ideas of what they want in their lives. To me, that's what critical thinking is: taking the resources that you have available to you and applying them in a way that... It's not always going to be a linear, $x-y-z$ process. But trying to take the information that you have and use it in a way that is getting the outcome that you want or the patient wants. - Student, face-to-face interview.

Cipolle et al. (2012) affirmed that what qualifies a pharmacist to assume clinical responsibilities towards the patient is the application of a unique knowledge base and set of clinical skills using a systematic thought process to assess the needs of a patient, identify and resolve drug therapy problems, and prevent those problems from occurring. Many participants talked about this thought process in generic terms, meaning a rational, structured way to make clinical decisions. However, some participants clearly named it, as the following faculty member:

So it brings you down to a different thought process. Well, it's not really a different thought process, it's the pharmaceutical care thought process. It's much more in-depth than looking at "Oh, you have high blood pressure and so I'm going to put you on Losartan". I don't think that's critical thinking. They have high blood pressure, why? What's the reason for their high blood pressure? So you have to dig down deeper into it and then, once you've dug down deeper into it, then okay, we have these medications which are indicated for mild hypertension. Well, we have four to choose from. Why would you choose one of these over 
another? You have to be able to articulate, go down deeper and choose the therapy that will fit best with the patient and the patient's medication experience. - Faculty.

The pharmacotherapy workup was mentioned several times as the framework that needs to be in place before one uses the needed flexibility to explore alternatives while thinking critically. The pharmacotherapy workup, as proposed by Cipolle et al. (2012), is the cognitive work occurring in the mind of a pharmacist while caring for a patient. It takes place during the patient care process in pharmaceutical care, where the pharmacists: assess the patient's drug related needs; identify any drug therapy problems that might be occurring; develop a care plan together with the patient; and determine the actual outcomes of the interventions proposed. In order to identify drug therapy problems, the pharmacist should always assess each medication used by the patient in terms of its indication, effectiveness, safety and convenience for that specific patient.

Because critical thinking gives us options and those four steps [indication, effectiveness, safety, and convenience] help guide the quality of the care we give. You wouldn't want to use critical thinking and come up with novel solutions that are going to be harmful. You want to keep it still effective and safe. So the four guidelines let you be creative and come up with solutions and know whether or not you've hit the end of the gray zone; whether or not you've gone too far, like: "I don't dare give them 120 milligrams of an ACE inhibitor. We probably ought to switch to something else by now". So it helps you identify where the boundaries are: "I can't go any farther. It wouldn't be safe any longer" - Student, focus group.

The pharmacotherapy workup was not claimed to be a magic formula for critical thinking in pharmacy, but it was highly associated with the idea of applying critical thinking skills in pharmacy practice focused on patient care. According to the participants, critical thinking is not about finding the 'right answer'. It implies a thinking process that enables one to go through a situation or problem and get a deeper and clearer understanding of what is going on in that specific condition.

It is important to highlight that the College of Pharmacy in which this research was conducted places great emphasis on preparing pharmacists for clinical practice. One of its goals listed in the Strategic Plan is to "partner with the profession of pharmacy in making a patient-centered pharmacy practice the standard of care and a vital part of the health care delivery system". It 
would be expected, therefore, that the PharmD curriculum emphasize critical thinking as a way to achieve that goal. The association between critical thinking and clinical practice has been extensively discussed by several authors (Daly, 1998; Facione, 2013; Scott et al., 1998) and excellence in professional judgment is considered the result of the sound use of critical thinking skills. The connection, thus, between pharmaceutical care and critical thinking seems rather natural in this context, from our perspective.

\section{Final considerations}

Critical thinking has become a constant element in the discourses on pharmacy practice and the development of this competency has been emphasized in the professional pharmacy curriculum. The movement from vaguely knowing critical thinking to understanding and clarifying its meaning, to applying it in practice, might lead to the expansion of the frontiers of knowledge in this field. This study added one more building block to the understanding of critical thinking in pharmacy. Educators, accrediting bodies, and employers claim that critical thinking is an essential skill to a competent pharmacist. It is time to move beyond "we know it when we see it" and focus equal attention on the systematic study of critical thinking in pharmacy practice. We believe that with a refined definition of what constitutes critical thinking in pharmacy practice related to patient care, the development of discipline-specific measures should be the following step.

The inclusion of creativity among the habits leading to critical thinking is one of the remarkable differences of how this skill set is understood in pharmacy. Since this research was conducted in one college of pharmacy, we argue that further investigation is warranted in order to deepen our understanding on these differences.

Talking about critical thinking in guidelines, books, and papers is not enough. Students need to engage in the process in the classroom. In order for it to happen, students and professors must be committed to an active learning process. Pharmacy education should move away from curriculum centered approaches and acknowledge the student and the learning process as the principal focus of their strategies in the classroom framework. 
According to the findings of this study, the link to the patient should not be lost, at the risk of dismantling the essence of the professional education leading to the PharmD degree itself. As emphasized by the participants in this study, background knowledge is important, but experience with patients, and their unique situations, is paramount for the development of critical thinking skills. In the world of patient care, professionals usually make decisions in uncertain situations where there is no right answer and so the thought process cannot be linear. In this environment, the pharmacist has to be able to be inquisitive, ask questions, be creative, connect information, and use previous experiences to make the best possible decision for that specific individual.

The rational thought process proposed in the pharmaceutical care theoretical framework (Cipolle et al., 2012), assessing patients' medications indication, effectiveness, safety and convenience, in this specific order, appears to play a pivotal role as the structure/ skeleton pharmacists use to go organize their thought as they think creatively and critically about their patients' health problems. This skeleton provides pharmacists with a reference point to keep them connected to their specific professional responsibilities, which is to guarantee that all of a patient's medications are appropriately indicated, effective, safe and convenient to be taken as recommended.

The Accreditation Council for Pharmacy Education (ACPE) has embraced pharmaceutical care as the mission of pharmacy profession and, therefore, colleges and schools of pharmacy should make every effort needed to connect what has been taught and learned in the classroom with the ultimate goals of pharmacy practice - the patient wellbeing.

We are facing a world that is becoming increasingly more complex. The decisions we make can well have significant long-term implications both for ourselves and for those who follow us. If we can successfully prepare students for that world, we will, by implication, prepare them for the diversities intrinsic to it. The task under focus is to find ways to teach in a manner that students learn to reason well through issues embodied in change, complexity, and diversity. Critical thinking is an important skill set that equips pharmacists with cognitive tools to properly address those issues. There is still much to be done and to be discovered in this field and we believe that the findings of this study represent a significant contribution to the preparation of pharmacists committed to effective patient care. 


\section{Acknowledgements}

We would like to thank all participants in this study.

\section{Referências}

Accreditation Council for Pharmacy Education - ACPE (2006). Accreditation standards and guidelines for the professional program in pharmacy leading to the Doctor of Pharmacy degree. Chicago: Accreditation Council for Pharmacy Education.

American Association of Colleges of Pharmacy - AACP (1989). Commission to Implement Change in Pharmaceutical Education. What is the mission of pharmaceutical education? Background paper I. Retrieved from: http://www.aacp.org/resources/historicaldocuments/Documents/Background Paper1.pdf

American Association of Colleges of Pharmacy - AACP (1991). Commission to Implement Change in Pharmaceutical Education. Background paper II: entry level curricular outcomes, curricular content, and educational process. Retrieved from: http://www.aacp.org/resources/historicaldocuments/ Documents/BackgroundPaper2.pdf.

Austin, Z., Gregory, P. A. M., \& Chiu, S. (2008). Use of reflection-in-action and selfassessment to promote critical thinking among pharmacy students. American Journal of Pharmaceutical Education, 72(3), Article 48.

Bartlett, D. J., \& Cox, P. D. (2002). Measuring change in students' critical thinking ability: Implications for health care education. Journal of Allied Health, 31(2), 6469.

Bloom, B. S. (1956). Taxonomy of educational objectives, Handbook 1: Cognitive domain (1st ed.). New York: David McKay Company.

Cipolle, R. J., Strand, L. M., \& Morley, P. C. (2012). Pharmaceutical care practice: The patient centered approach to medication management (3rd ed.). New York, NY: McGraw-Hill.

Daly, W. M. (1998). Critical thinking as an outcome of nursing education. What is it? Why is it important to nursing practice? Journal of Advanced Nursing, 28(2), 323-31.

Droege, M. (2003). The role of reflective practice in pharmacy. Education for Health, 1(16), 68-74.

Emerson, R. M., Fretz, R. I., \& Shaw, L. L. (1995). Writing ethnographic fieldnotes. Chicago: The University of Chicago Press.

Facione, N. C., \& Facione, P. A. (2008). Critical thinking and clinical judgment. In N. C. Facione \& P. A. Facione (Eds.), Critical thinking and clinical reasoning in the health sciences: A teaching anthology. Millbrae, CA: The California Academic Press.

Facione, P. A. (1990). Executive Summary - Critical thinking: A statement of expert consensus for purposes of educational assessment and instruction. Millbrae, CA: The California Academic Press. 
Facione, P. A. (2013). Critical thinking: What it is and why it counts, Insight Assessment - Measuring Thinking Worldwide. Available at: http://www.insightasse ssment.com

Hooks, B. (2010). Teaching critical thinking: Practical wisdom. New York, NY: Routledge.

Lopes, S. F., Vieira, R. M., \& Moreira, A. (2014). Promoção do pensamento crítico na educação e formação de adultos. In R. M. Vieira, C. Tenreiro-Vieira, I. SáChaves, \& C. Machado (Orgs.), Pensamento crítico na educação: Perspectivas atuais no panorama internacional (pp. 105-118). Aveiro: Universidade de Aveiro Editora.

Paul, R. (1990). Critical thinking: What every person needs to survive in a rapidly changing world. Rohnert Park, CA: Center for Critical Thinking and Moral Critique.

Paul, R., Elder, L., \& Bartell, T. (1997). California teacher preparation for instruction in critical thinking: Research findings and policy recommendations. Sacramento: California Commission on Teacher Credentialing.

Phillips, C., R., Chesnut, R. J., \& Rospond, R. M. (2004). The California critical thinking instruments of benchmarking, program assessment, and directing curricular change. American Journal of Pharmaceutical Education, 68(4), Article 101.

Rubin, H. J., \& Rubin, I. S. (2005). Qualitative interviewing: The art of hearing data (2nd ed). Thousand Oaks: Sage Publications.

Scott, J. N., Markert, R. J., \&Dunn, M. M. (1998). Critical thinking: Change during medical school and relationship to performance in clinical clerkships. Medical Education, 32, 14-18.

Seldomridge, L. A., \& Walsh, C. M. (2006). Measuring critical thinking in graduate education: What do we know? Nurse Educator, 31(3), 132-137.

Shor, I., \& Freire, P. (1987). A pedagogy for liberation: Dialogues on transforming education. South Hadley, Massachusetts: Bergin \& Garvey Publishers.

Strand, L. M., \& Morley, P. C. (1987). Evolving health care systems: Academic implications for teaching methodologies with emphasis on administration and practice. American Journal of Pharmaceutical Education, 51, 402-406.

Willingham, D. T. (2007). Critical thinking: Why is it so hard to teach? American Educator, 2007, 8-19.

Wolcott, H. F. (2005). The art of fieldwork (2nd ed.). Walnut Creek, CA: Altamira Press. 


\title{
PENSAMENTO CRÍTICO NO CONTEXTO DA PRÁTICA CLÍNICA: A NECESSIDADE DE REINVENTAR A EDUCAÇÃO FARMACÊUTICA
}

\begin{abstract}
Resumo
Com o objetivo de compreender como as práticas pedagógicas influenciam o desenvolvimento de competências clínicas em estudantes de farmácia, os autores conduziram uma etnografia crítica utilizando os métodos de observação participante, grupos focais e entrevistas em profundidade com estudantes e professores de uma das dez maiores Faculdades de Farmácia dos Estados Unidos. Os resultados que emergiram de dois semestres de pesquisa de campo mostram que o conhecimento farmacêutico tradicionalmente ensinado não é suficiente para preparar os estudantes para a prática clínica. A incorporação de experiências práticas e da filosofia e arcabouço teórico da atenção farmacêutica no currículo é necessária para preparar os estudantes para o cuidado direto das pessoas. Os resultados deste estudo poderão contribuir para a construção de atividades de ensino que efetivamente desenvolvam competências essenciais nos futuros cuidadores.
\end{abstract}

Palavras-chave

Educação farmacêutica; Prática clínica; Atenção farmacêutica; Pesquisa qualitativa

EL PENSAMIENTO CRÍTICO EN EL CONTEXTO DE LA PRÁCTICA CLÍNICA: LA NECESIDAD DE REINVENTAR LA EDUCACIÓN FARMACÉUTICA

\section{Resumen}

Con la finalidad de entender como las prácticas pedagógicas influyen en el desarrollo de las habilidades de pensamiento crítico de estudiantes de 


\section{Erika Lourenço de Freitas \& Djenane Ramalho-de-Oliveira}

farmacia, se utilizaron la etnografía crítica y los métodos de observación participante, grupos de discusión y entrevistas en profundidad con los estudiantes y profesores en una de las diez mejores Facultades de Farmacia de los Estados Unidos. El resultado que surgió de dos semestres de trabajo de campo sugiere que el conocimiento farmacéutico enseñado tradicionalmente no es suficiente para preparar a los estudiantes de farmacia para la práctica clínica. Además de la capacidad para recuperar información, la educación farmacéutica puede beneficiarse si se incorporan en el currículo las experiencias prácticas y la filosofía de atención farmacéutica para preparar a los farmacéuticos para ofrecer atención directa al paciente. El conocimiento que surgió de este estudio permitirá a los educadores a diseñar actividades de aprendizaje para desarrollar con mayor eficacia estas habilidades esenciales en nuestros futuros cuidadores.

Palabras-clave

Educación farmacéutica; Práctica clínica; Atención farmacéutica, Investigación cualitativa

Recebido em junho/2015 Aceite para publicação em novembro/2015

i Department of Pharmacy Practice, Regis University School of Pharmacy, Denver, USA.

ii Centro de Estudos em Atenção Farmacêutica, Faculdade de Farmácia, Universidade Federal de Minas Gerais, Belo Horizonte, Brasil.

Toda a correspondência relativa a este artigo deve ser enviada para: Erika Lourenço de Freitas, Regis University, Department of Pharmacy Practice, School of Pharmacy, 3333 Regis Blvd, Denver, CO 80221, USA. E-mail: elourencodefreitas@ regis.edu. 